\title{
Applying Factor Analysis on the Financial Ratios of Turkey's Top 500 Industrial Enterprises
}

\author{
Aysa Ipek Erdogan ${ }^{1}$ \\ ${ }^{1}$ Department of Tourism Administration, Bogazici University, Istanbul, Turkey \\ Correspondence: Aysa Ipek Erdogan, Department of Tourism Administration, Bogazici University, Hisar \\ Kampus, 34342, Bebek, Istanbul, Turkey. Tel: 90-212-359-7114. E-mail: aysa.erdogan@boun.edu.tr
}

Received: February 17, 2013

Accepted: March 5, 2013

Online Published: April 23, 2013

doi:10.5539/ijbm.v8n9p134

URL: http://dx.doi.org/10.5539/ijbm.v8n9p134

\begin{abstract}
Factor analysis is a method that is used to reduce several variables into fewer dimensions that are called factors. This study conducts factor analysis on the financial ratios of the top 500 industrial enterprises in Turkey for 2010. The purpose of the study is to group the financial ratios into categories and eliminate redundancy among them. Our results provide partial support for the textbook classification of financial ratios.
\end{abstract}

Keywords: financial ratio analysis, factor analysis, classification of financial ratios, Turkey

\section{Introduction}

Financial ratios are valuable tools in understanding and monitoring a company's financial position and performance. They ease comparison because they control for the effect of size on the financial variables. Financial ratios are generally broken into categories according to the information they provide. Profitability ratios provide information on the success of a firm in generating profits. Financial leverage ratios are used to evaluate the degree of a company's fixed financing obligations and its ability to service the source of financing. Liquidity ratios are used to evaluate a firm's ability to satisfy its short-term debt obligations. Efficiency ratios provide information on the ability of the firm to manage its assets.

There are quite a large number of financial ratios and certain studies in the literature resort to factor analysis to determine the factors that explain the financial ratios in a smaller set of new composite dimensions (e.g., Pinches, Mingo \& Caruthers, 1973; Chen \& Shimerda, 1981; Taffler, 1982; Ali \&Charbaji, 1994; Ganesalingam \& Kumar, 2001; Ugurlu \& Aksoy, 2006; De, Bandyopadhyay \& Chakraborty, 2011; Chen, 2011). Factors analysis is a technique that is used to describe variability among observed variables in terms of fewer unobserved underlying dimensions which are called factors. To perform such a task, it examines the pattern of correlations among the variables. Variables that are highly correlated (either positively or negatively) are considered to be influenced by the same factors, and the data can be described in a smaller number of concepts.

This paper applies factor analysis on the financial ratios of the top 500 industrial enterprises in Turkey for 2010 . The purpose is to find out whether the financial ratios are linearly related to a smaller number of unobservable factors. The paper is organized as follows. Section 2 includes a review of the literature. Section 3 presents the data, and section 4 depicts the research methodology. Section 5 describes the variables. Section 6 discusses the empirical results of the study, and section 7 concludes.

\section{Literature Review}

In the literature, certain studies use factor analysis to develop empirically based classifications of financial ratios. Pinches et al. (1973) obtain the financial ratio factor patterns in the US and analyze whether these patterns are stable in the long term. They find that the composition of the groups of financial ratios is reasonably stable over time.

Chen and Shimerda (1981) demonstrate that the selection of a representative ratio for each factor can be sufficient to capture most of the information provided by all the ratios for US firms. De et al. (2010) also show that representative ratios for each factor can account for most of the information available in the original larger set of ratiosfor Indian firms.

Salmi, Virtanen and Yli-Olli (1990) analyze whether they can provide support for the standard text-book classification of financial ratios for Finnish firms. Their results do not lend direct support to the conventional 
classification. Ali and Charbi (1994) also find that there is a difference between the empirical and theoretical classification of financial ratios for international commercial airlines.

Studies that aim to develop prediction models for corporate financial distress also make use of factor analysis (e.g., Libby, 1975, for the US; Taffler, 1982, for the UK; Ganesalingam \& Kumar, 2001, for Australia; Mahmoud, 2008, for Egypt; Chen, 2011, for Taiwan). These studies generally conduct discriminant analysis or logistic regression to derive a linear combination of the financial ratios which best discriminate between financially distressed and financially healthy firms. To avoid the inclusion of the financial ratios that measure closely related aspects of the firm in the models and to avoid multicollinearity, these studies generally use factor analysis as a data reduction technique to identify the financial dimensions represented by the ratios.

There are also studies on Turkish firms that used factor analysis to determine the factors that explain the financial ratios in a smaller set of new composite dimensions. Karatas (2002) makes a detailed multivariate comparison of foreign-owned firms and domestically-owned firms in terms of conduct and performance. The author applies factor analysis to financial ratios as a means of eliminating redundancy among them before conducting discriminant analysis and logistic regression. Ugurlu \& Aksoy (2006) use factor analysis to identify the representative financial ratios for each factor before conducting discriminant analysis todevelop a model for failure prediction. Ocal, Oral, Erdis \& Vural (2007) apply factor analysis to the financial ratios of Turkish construction companies to determine the financial indicators that can be used to analyze the financial state of the industry.

\section{Data}

Our sample is composed of the top 500 industrial enterprises in Turkey for 2010. The distribution of the sample according to industry is presented in Table 1.

Table 1. Distribution of the sample according to industry

\begin{tabular}{lc}
\hline Industry & Number of Firms \\
\hline Mining and Quarrying & 14 \\
Food, Beverages and Tobacco & 105 \\
Textile, Wearing Apparel, Leather and Shoe & 51 \\
Forest Products and Furniture & 10 \\
Paper, Paper Products and Printing & 16 \\
Chemicals, Petroleum Products, Rubber and Plastic Products & 81 \\
Non-Metal Mineral Products & 36 \\
Basic Metal & 70 \\
Metal Products and Machinery & 60 \\
Automotive Industry & 41 \\
Other & 4 \\
Electricity & 12 \\
TOTAL & 500 \\
\hline
\end{tabular}

\section{Research Methodology}

Factor analysis is a technique that is used to condense several observed variables into fewer dimensions that are called factors (Hair, Black, Babin \& Anderson, 2009). To perform such a task, it examines the pattern of correlations among the variables and identifies whether the correlations can be summarized in terms of a smaller number of unobserved factors. Variables that are highly correlated (either positively or negatively) are considered to be influenced by the same factor.

Factor analysis can also be used as a data reduction technique. This can be achieved by reducing the information of several variables into a set of weighted linear combinations of those variables and substituting these linear combinations for the original variables. The linear combination of the variables is in the following form: 


$$
F S_{i j}=\beta_{1} X_{i 1}+\beta_{2} X_{i 2}+\ldots . .+\beta_{p} X_{i p}
$$

Where: $\mathrm{FS}_{\mathrm{ij}}=$ estimated factor score of object I for factor $\mathrm{j}$.

$\beta_{\mathrm{p}}=$ estimated factor score coefficient for variable $\mathrm{p}$.

$\mathrm{X}_{\mathrm{ip}}=\mathrm{p}^{\text {th }}$ variable for object i.

\section{Variables}

The financial variables used in our study are shown in Table 2 . The financial data used in calculating the variables is provided by Istanbul Chamber of Industry.

Table 2. Description of the variables used in factor analysis

\begin{tabular}{ll}
\hline Variables & \\
\hline Profitability Ratios & Net Profit before Taxes / Net Sales \\
$\begin{array}{l}\text { Pretax Profit Margin } \\
\text { Return on Equity }\end{array}$ & Net Profit before Taxes / Stockholders' Equity \\
Efficiency Ratios & \\
Asset Turnover & Net Sales / Total Assets \\
Equity Turnover & Net Sales / Stockholders' Equity \\
$\begin{array}{l}\text { Productivity Ratios } \\
\text { Labor Productivity }\end{array}$ & Gross Value Added / Number of Employees \\
Capital Productivity & Gross Value Added / Total Assets \\
Capital Structure Ratio & \\
Debt Ratio & Total Liabilities / Total Assets \\
Other Ratios & \\
Capital Intensity & Total Assets / Number of Employees \\
Export Intensity & Exports / Net Sales \\
\hline
\end{tabular}

\section{Empirical Findings}

We evaluate the factorability of the correlation matrix of the variables with a visual examination of the correlations. Table 3 shows the correlation matrix.

Inspection of the correlations shows that 19 of the 36 correlations (53\%) are significant at the 0.01 level. Because capital intensity does not have any significant correlation, it may not be part of any of the resulting factors.

The evaluation of the overall significance of the correlation matrix is done with Bartlett's Test. Bartlett's Test shows that the correlation matrix is significant at the 0.000 level. Evaluation of the adequacy of each variable for factor analysis is done with Measure of Sampling Adequacy (MSA). None of the variables have an unacceptable MSA value which is below 0.5 . MSA value which quantifies the degree of inter-correlations among the variables falls in the acceptable range with a value of 0.5 .

Communalities show the proportion of variance of each variable accounted for by the factors. Table 4 presents the communalities of the variables for our factor solution.

Capital intensity has a comparably low communality than the other variables. A small communality shows that a significant portion of the variance is unaccounted for by the factor solution. Although variables with low communalities are candidates for deletion from the analysis, we ignore this variable and continue with the interpretation of the solution.

The initial solution estimation of the factor analysis is based on principal component method. Varimax rotation is applied for the final solution. In the analysis, lowest factor loading to be considered significant is \pm 0.55 . Factor analysis result is presented in Table 5.

Factor 1 which is named "Productivity", has two variables with significant loadings. These two variables, which 
are labor productivity and capital productivity, increase and decrease together. Factor 2 which is named "Profitability and Capital Structure" has three variables with significant loadings.

Table 3. Correlations among variables

\begin{tabular}{|c|c|c|c|c|c|c|c|c|c|c|}
\hline & $\begin{array}{c}\text { Pretax } \\
\text { Profit } \\
\text { Margin } \\
\end{array}$ & $\begin{array}{l}\text { Return } \\
\text { on } \\
\text { Equity }\end{array}$ & $\begin{array}{c}\text { Asset } \\
\text { Turnover }\end{array}$ & $\begin{array}{l}\text { Equity } \\
\text { Turnover }\end{array}$ & $\begin{array}{c}\text { Labor } \\
\text { Productivity }\end{array}$ & $\begin{array}{c}\text { Capital } \\
\text { Productivity }\end{array}$ & $\begin{array}{l}\text { Debt } \\
\text { Ratio }\end{array}$ & $\begin{array}{c}\text { Capital } \\
\text { Intensity }\end{array}$ & $\begin{array}{c}\text { Export } \\
\text { Intensity }\end{array}$ & $\begin{array}{l}\text { Sales from } \\
\text { Production } \\
\text { / Net Sales }\end{array}$ \\
\hline Pretax & 1.000 & 0.515 & -0.264 & -0.196 & 0.179 & 0.195 & -0.422 & -0.049 & 0.055 & 0.060 \\
\hline \multicolumn{11}{|l|}{ Profit } \\
\hline \multicolumn{11}{|l|}{ Margin } \\
\hline Return on & & 1.000 & 0.113 & 0.053 & 0.157 & 0.221 & -0.197 & -0.019 & -0.049 & 0.012 \\
\hline \multicolumn{11}{|l|}{ Equity } \\
\hline Asset & & & 1.000 & 0.500 & 0.000 & 0.105 & 0.162 & -0.042 & -0.001 & -0.145 \\
\hline \multicolumn{11}{|l|}{ Turnover } \\
\hline Equity & & & & 1.000 & -0.006 & -0.021 & 0.339 & 0.077 & -0.056 & 0.157 \\
\hline \multicolumn{11}{|l|}{ Turnover } \\
\hline Labor & & & & & 1.000 & 0.895 & -0.011 & -0.082 & -0.031 & 0.245 \\
\hline \multicolumn{11}{|l|}{ Productivity } \\
\hline Capital & & & & & & 1.000 & -0.080 & -0.052 & 0.055 & 0.039 \\
\hline \multicolumn{11}{|l|}{ Productivity } \\
\hline Debt Ratio & & & & & & & 1.000 & 0.000 & -0.065 & 0.122 \\
\hline Capital & & & & & & & & 1.000 & 0.153 & -0.138 \\
\hline \multicolumn{11}{|l|}{ Intensity } \\
\hline Export & & & & & & & & & 1.000 & -0.296 \\
\hline \multicolumn{11}{|l|}{ Intensity } \\
\hline Sales from & & & & & & & & & & 1.000 \\
\hline \multicolumn{11}{|l|}{ Production / } \\
\hline Net Sales & & & & & & & & & & \\
\hline
\end{tabular}

Note: Bolded values show correlations significant at the 0.01 significance.

Overall Measure of Sampling Adequacy: 0.5.

Bartlett Test of Sphericity: 1046, Significance: 0.000 .

Table 4. Communality values for the variables

\begin{tabular}{lc}
\hline Variable & Communality \\
\hline Pretax Profit Margin & 0.754 \\
Return on Equity & 0.769 \\
Asset Turnover & 0.728 \\
Equity Turnover & 0.722 \\
Labor Productivity & 0.957 \\
Capital Productivity & 0.945 \\
Debt Ratio & 0.544 \\
Capital Intensity & 0.221 \\
Export Intensity & 0.560 \\
Sales from Production / Net Sales & 0.629 \\
\hline
\end{tabular}

Pretax profit margin and return on equity increase (decrease) together and move in opposite direction to debt ratio. This negative relationship between profitability ratios and debt ratio is noteworthy because it reminds us the suggestion that debt ratio has a negative impact on financial performance due to the debt overhang problem (Myers, 1977).

Factor 3 which is named "Efficiency" has two variables with significant loadings. These two variables, which 
are asset turnover and equity turnover, increase (decrease) together. Factor 4, which is named "Export Intensity and Proportion of Sales from Production", has two variables with significant loadings. These two variables, which are export intensity and sales from production/net sales, move in opposite directions. This result signals that export intensive firms also perform merchandising activities.

Because our profitability ratios and efficiency ratios separately load on the same factors, we can say that our results provide partial support for the standard text-book classification of financial ratios.

\section{Conclusion}

Table 5. Factors solution (top 500 industrial enterprises, 2010)

\begin{tabular}{lll}
\hline Factors & Variables that significantly load on the factor & Factor Loading \\
\hline 1 Productivity & Labor Productivity & 0.96 \\
& Capital Productivity & 0.96 \\
2 Profitability and Capital Structure & Pretax Profit Margin & 0.82 \\
& Return on Equity & 0.82 \\
& Debt Ratio & -0.60 \\
3 Efficiency & Asset Turnover & 0.84 \\
& Equity Turnover & 0.83 \\
Export Intensity and Proportion of Sales from & Exports/Net Sales & 0.74 \\
Production & Sales from Production/Net Sales & -0.78 \\
Bartlett's Test (Significance) & 0.000 & \\
Measure of Sampling Adequacy & 0.56 & $22.72 \%$ \\
Total Variance Explained & 500 & \\
$\mathrm{~N}$ & &
\end{tabular}

This paper conducts factor analysis on the financial ratios of the top 500 industrial enterprises in Turkey for 2010 . Our purpose is to define a set of factors which can describe the ratios in a smaller number of concepts. Factor analysis also helps us to analyze the structure of the interrelationships among the ratios. Concerning thestructure of the ratios, there are four separate and distinct factors. Within the "Profitability and Capital Structure" factor, there is a tradeoff between pretax profit margin and return on equity versus the debt ratio. This finding provides support for the debt overhang theory which argues that excessive corporate debt can lead firms to underinvest in profitable projects. Export intensity and sales from production/net sales significantly load on the same factor, and they move in opposite directions. This may signal that export intensive firms are also involved in merchandising activities. Labor productivity and capital productivity significantly load on the same factor, and they move in the same direction. Asset turnover and equity turnover also load on the same factor and increase (decrease) together.

This paper was prepared with the purpose of identifying the sets of related financial ratios. The use of factor analysis as a data reduction technique is not targeted. The financial ratios can be replaced with a new smaller set of variables created from factor scores. However, the assessment of content validity, dimensionality, reliability and validity should be done before the application of data reduction. We leave this assessment as a suggestion for future research.

\section{References}

Aktan, S. (2009). Financial statement indicators of financial failure: An empirical study on Turkish public companies during the November 2000 and February 2001 crisis. Investment Management and Financial Innovations, 6(1), 163-173.

Ali, H. F., \& Charbaji, A. (1994). Applying factor analysis to financial ratios of international commercial airlines. International Journal of Commerce and Management, 4(1-2), 25-37. http://dx.doi.org/10.1108/eb047285 
Chen, K. H., \& Shimerda, T. A. (1981). An empirical analysis of useful financial ratios. Financial Management, 10(1), 51-60. http://dx.doi.org/10.2307/3665113

Chen, M. (2011). Predicting corporate financial distress based on integration of decision tree classification and logistic regression. Expert Systems with Applications, 38(9), 11261-11272. http://dx.doi.org/10.1016/j.eswa.2011.02.173

De, A., Bandyopadhyay, G., \& Chakraborty, B. N. (2011). Application of factor analysis on the financial ratios of Indian cement industry and validation of the results by cluster analysis. Journal of Business Studies Quarterly, 2(3), 13-31.

Ganesalingam, S., \& Kumar, K. (2001). Detection of financial distress via multivariate statistical analysis. Managerial Finance, 27(4), 45-55. http://dx.doi.org/10.1108/03074350110767132

Hair, J. F., Black, W. C., Babin, B. J., \& Anderson, R. E. (2009). Multivariate data analysis. Upper Saddle River: Prentice-Hall.

Karataş, A. (2002). Performance of direct foreign investments in Turkey. Doctoral Dissertation. Boğaziçi University, Istanbul, Turkey.

Libby, R. (1975). Accounting ratios and the prediction of failure: Some behavioral evidence. Journal of Accounting Research, 13(1), 150-161. http://dx.doi.org/10.2307/2490653

Myers, S. (1977). The determinants of corporate borrowing. Journal of Financial Economics, 5(2), 147-175. http://dx.doi.org/10.1016/0304-405X(77)90015-0

Ocal, M. E., Oral, E., Erdis, E., \& Vural, G. (2007). Industry financial ratios-application of factor analysis in Turkish construction industry. The Building and Environment, 2(3), 385-392. http://dx.doi.org/10.1016/j.buildenv.2005.07.023

Pinches, G. E., Mingo, K. A., \& Caruthers, J. K. (1973). The stability of financial patterns in industrial organizations. The Journal of Finance, 28(2), 389-396. http://dx.doi.org/10.2307/2978312

Salmi, T., Virtanen, I., \& Yli-Olli, P. (1990). On the classification of financial ratios: A factor and transformation analysis of accrual, cash flow, and market-based ratios. Acta Wasaensia. University of Vaasa, Vaasa, Finland. No. 25.

Tan, P. M. S., Koh, H. C., \& Low, L. C. (1997). Stability of financial ratios: A study of listed companies in Singapore. Asian Review of Accounting, 5(1), 19-39. http://dx.doi.org/10.1108/eb060680

Taffler, R. J. (1982). Forecasting company failure in the UK using discriminant analysis and financial ratio data. Journal of the Royal Statistical Society, 145(3), 342-358. http://dx.doi.org/10.2307/2981867

Ugurlu, M., \& Aksoy, H. (2006). Prediction of corporate financial distress in an emerging market: The case of Turkey. Cross Cultural Management: An International Journal, 13(4), 277-295. http://dx.doi.org/10.1108/13527600610713396 